\title{
Fatty acids and antioxidant capacities of three Centaurea L. species
}

\author{
Pelin TAŞTAN ${ }^{1}$ (D), Burcu TÜZÜN 2 (D), Bijen KIVÇAK ${ }^{2}$ (D) , Tuğçe FAFAL 2 (D) \\ 1 Department of Pharmacognosy, Faculty of Pharmacy, İzmir Katip Çelebi University, Çiğli, İzmir, Turkey \\ 2 Department of Pharmacognosy, Faculty of Pharmacy, Ege University, 35100, Bornova, İzmir, Turkey. \\ * Corresponding Author. E-mail: pelintastan35@gmail.com (P.T.); Tel. +90-533-963 7417.
}

Received: 30 April 2021 / Revised: 31 August 2021 / Accepted: 04 September 2021

\begin{abstract}
The aim of this study is to determine the fatty acid compositions and antioxidant activities of three Centaurea species as Centaurea iberica, C. urvillei ssp. hayekiana, and C. urvillei ssp. nimrodis and compare them with each other. As a result of fatty acid determination by GC MS method, oleic acid and linoleic acid were found as the main fatty acids in these Centaurea species. Polyunsaturated fatty acids (PUFAs) were determined at 58.66\%, 46.98\%, 62.22\% in C. iberica, C. urvillei ssp. hayekiana and C. urvillei ssp. nimrodis, respectively. Antioxidant activities of methanolic extracts of three Centaurea species were evaluated by DPPH, ABTS and CUPRAC assays. The methanol extract of $C$. urvillei ssp hayekiana showed the highest antioxidant activity in direct proportion to the total amount of phenolic and flavonoid substances. The fact that the antioxidant activities of these three species and fatty acid analyzes have not been compared in previous studies is important in that this study is the first.
\end{abstract}

KEYWORDS: Fatty acid; Centaurea iberica; C. urvillei ssp. hayekiana; C. urvillei ssp. nimrodis; antioxidant activity.

\section{INTRODUCTION}

Turkey has a wide flora with approximately 9000 plants. Asteraceae is one of the most widespread families in Turkey. The genus Centaurea contains 180 taxa, 120 of which are endemic in Turkey. C. urvillei DC. ssp. hayekiana Wagenitz and C. urvillei DC. ssp. nimrodis Boiss. \& Hausskn. are endemic species which are spread in the east Anatolia [1-3]. In ethnobotanical use, these species are used as antirheumatic, expectorant, antidiarrhoeal, diuretic, choleretic, stomachic, astringent, cytotoxic, antibacterial, antipyretic and tonic [4-6]. Based on the literature information, Centaurea species have antioxidant, antimicrobial, antirheumatic and anti inflammatory properties [7-10]. These effects are known to be due to the secondary metabolites as flavonoids, steroids, volatile constituents, sesquiterpene lactones and fatty acids which is common in Centaurea species [11-16].

There are various studies on the fatty acid contents and antioxidant activities of Centaurea species. [12, 17-22]. Bouafia and friends made comparison of fatty acid content and antioxidant activities of various Centaurea species according to months and different drogs of plants. According to the results, the most important difference was that the roots had a high amount of UFA C18:2 and C18:3, while the roots' bark and the leaves were mainly high in C20:1. However, in general, all results show that the fatty acid content of the plant is abundant and the plant has antioxidant activity. In a different research, total phenolic content (mg GAE/g), DPPH ( $\mathrm{IC}_{50}$ ) and reducing power $\left(\mathrm{IC}_{50}\right)$ of $C$. kroumirensis (Coss.) and C. sicula L. subsp. sicula were investigated. In the comparison made using different extraction techniques, the total phenolic content ranged from 61.11 to $4.79 \mathrm{mg} \mathrm{GAE} / \mathrm{g}$ and from 28.25 to $8.32 \mathrm{mg}$ GAE/g for C. kroumirensis and C. sicula, respectively [23]. In the study examining the fatty acid profile of $C$. stenolepis, it was found that it is rich in sesquiterpene hydrocarbons, hexadecanoic acid and stem oil is rich in higher alkanes, fatty acids [24].

The fatty acid composition of C. iberica Trev. were previously investigated [12]. There were some antioxidant activity studies on different $C$. urvillei subspecies. C. urvillei ssp. armata, C. urvillei ssp. hayekiana and C. urvillei ssp. urvillei were analyzed in some previous studies $[25,26]$. Even if it is the same species, it is very difficult to obtain the same results with the effect of many factors such as the place where the plants were collected, the time, the parts used and the solvent used in the preparation of the extracts. The fatty acid

How to cite this article: Taştan P, Tüzün B, Kıvçak B, Fafal T. Fatty acids and antioxidant capacities of three Centaurea L. species. J Res Pharm. 2022; 26(1): 174-179. 
composition of $C$. urvillei ssp. nimrodis has not been previously studied. The aim of our study is to determine the fatty acid composition of plants by GC-FID analysis and antioxidant activities by various methods.

\section{RESULTS AND DISCUSSION}

The fatty acid compositions of C. iberica, C. urvillei ssp. hayekiana, and C. urvillei ssp. nimrodis are given in Table 1.

Table 1. Fatty acid compositions $(\%$, mean $\pm S D, n=3)$ of investigated Centaurea species.

\begin{tabular}{|c|c|c|c|}
\hline Fatty acids & C. iberica & $\begin{array}{l}\text { C. urvillei } \\
\text { ssp.hayekia } \\
\text { na }\end{array}$ & $\begin{array}{l}\text { C. urvillei } \\
\text { ssp. } \\
\text { nimrodis }\end{array}$ \\
\hline C 16:0 (palmitic acid) & $6.09 \pm 0.07 \mathrm{a}$ & $12.09 \pm 0.02$ & $2.82 \pm 0.03$ \\
\hline C 17:0 (heptadecanoic acid) & $0.59 \pm 0.01$ & $0.09 \pm 0.02$ & $2.37 \pm 0.05$ \\
\hline C 18:0 (stearic acid) & $5.87 \pm 0.02$ & $4.25 \pm 0.01$ & $5.24 \pm 0.01$ \\
\hline C 20:0 (arachidic acid) & $1.70 \pm 0.16$ & $2.44 \pm 0.21$ & $0.93 \pm 0.09$ \\
\hline C 22:0 (behenic acid) & $0.32 \pm 0.02$ & $2.62 \pm 0.11$ & $2.05 \pm 0.01$ \\
\hline$\sum \mathrm{SFA}^{\mathbf{b}}$ & $14.57 \pm 0.28$ & $21.49 \pm 0.37$ & $13.41 \pm 0.19$ \\
\hline C $18: 1 \omega 9$ (oleic acid) & $18.65 \pm 0.03$ & $28.09 \pm 0.08$ & $23.04 \pm 0.06$ \\
\hline 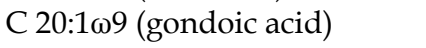 & $5.91 \pm 0.02$ & $0.14 \pm 0.01$ & $3.00 \pm 0.01$ \\
\hline 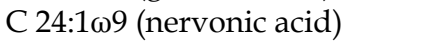 & - & $0.23 \pm 0.01$ & $0.34 \pm 0.03$ \\
\hline$\sum$ MUFA $^{\mathbf{b}}$ & $24.56 \pm 0.05$ & $28.46 \pm 0.10$ & $26.38 \pm 0.10$ \\
\hline C 18:2w6 (linoleic acid) & $29.85 \pm 0.07$ & $23.09 \pm 0.02$ & $31.08 \pm 0.02$ \\
\hline C 18:3w3 (a-linolenic acid) & $14.75 \pm 0.48$ & $8.27 \pm 0.42$ & $10.96 \pm 0.51$ \\
\hline 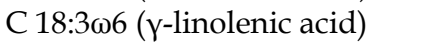 & $6.09 \pm 0.01$ & $4.75 \pm 0.01$ & $3.06 \pm 0.06$ \\
\hline C 20:3 $\omega 3$ (eicosotrienoic acid) & $3.08 \pm 0.02$ & $1.29 \pm 0.03$ & $4.04 \pm 0.01$ \\
\hline 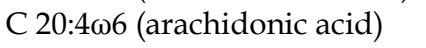 & $2.89 \pm 0.06$ & $4.58 \pm 0.07$ & $6.08 \pm 0.04$ \\
\hline$\sum$ PUFA $^{\mathbf{b}}$ & $56.66 \pm 0.49$ & $41.98 \pm 0.06$ & $55.22 \pm 0.09$ \\
\hline$\sum$ major fatty acids & 95.79 & 91.93 & 95.71 \\
\hline ¿other fatty acids & 4.21 & 8.07 & 4.99 \\
\hline
\end{tabular}

aValues reported are means \pm S.D., bSFA:Saturated fatty acids, MUFA:Monounsaturated fatty acids, PUFA:Polyunsaturated fatty acids

Twelve fatty acids were identified in C. iberica oil. The major fatty acids were linoleic acid (29.85\%), oleic acid $(18.65 \%)$ and linolenic acid $(14.75 \%)$. MUFAs were present with $24.56 \%$ and PUFAs were $56.66 \%$. Totaly, unsaturated fatty acids were present with $81.22 \%$ of total fatty acids. For C. urvillei ssp. nimrodis major fatty acids were determined as oleic acid (23.04\%) and linoleic acid (31.08\%). We also identified 13 fatty acids in oil of C. urvillei ssp. hayekiana and the major fatty acid was oleic acid (28.05\%). Other majör fatty acids were linoleic acid $(23.09 \%)$ and palmitic acid (12.09\%). MUFAs were present with $28.46 \%$ and PUFAs were $41.98 \%$. Totaly, unsaturated fatty acids were present with $70.44 \%$ of total fatty acids. For C. urvillei ssp. nimrodis major fatty acids oleic acid $(23.04 \%)$, linoleic acid $(31.08 \%)$ and linolenic acid $(10.96 \%)$. And also MUFAs were present with $26.38 \%$ and PUFAs were $55.22 \%$. Totaly, unsaturated fatty acids were present with $81.6 \%$ of total fatty acids for C. urvillei ssp. nimrodis. The antioxidant activities of our extracts of Centaurea species reported in Table 2 .

C. urvillei ssp. hayekiana was determined as the most active plant of the three plants with $17.18 \pm 0.86$ $\mu \mathrm{g} / \mathrm{ml} \mathrm{IC}_{50}, 98.43 \pm 1.34 \%$ (ABTS) and $1230 \pm 0.26 \mu \mathrm{g} / \mathrm{ml}$ (CUPRAC) values. A positive correlation between total flavonoid and phenolic contents and antioxidant activity of the extracts were observed. In addition, the yields of the extracts prepared from the plants were obtained in harmony with each other.

\section{CONCLUSION}


The fatty acid composition of $C$. urvillei ssp. nimrodis was investigated for the first time. In our study, oleic acid was detected as the major fatty acid in C. urvillei ssp. hayekiana $(28.09 \%)$ and C. urvillei ssp. nimrodis $(23.04 \%)$. However, linoleic acid was obtained as the major fatty acid in C. iberica oil. Oleic acid, linoleic acid, linolenic acid and palmitic acid were the most common major substances in different Centaurea species [12, 1722]. There is a report about the fatty acid composition of C. urvillei ssp. hayekiana, however there is no report including fatty acid compositions of C. urvillei ssp. nimrodis. Similar to our results Zengin et al. reported linoleic acid $(35.92 \%)$ as the major unsaturated fatty acid and palmitic acid $(16.24 \%)$ as the major saturated fatty acid in C. urvillei ssp. hayekiana from Konya, Turkey [22].

Table 2. Results of antioxidant activity, total phenolic and flavonoid contents of investigated Centaurea species.

\begin{tabular}{|c|c|c|c|c|c|c|}
\hline Species & $\begin{array}{c}\text { Yield of } \\
\text { methanol } \\
\text { extracts } \\
(\%)\end{array}$ & $\begin{array}{c}\text { DPPH IC } \\
(\mu \mathrm{g} / \mathrm{ml})\end{array}$ & $\begin{array}{c}\text { ABTS } \\
(\%)\end{array}$ & $\begin{array}{c}\text { CUPRAC } \\
(\mu \mathrm{g} / \mathrm{ml})\end{array}$ & TPC (mg/g)a & $\begin{array}{c}\text { TFC } \\
(\mathrm{mg} / \mathrm{g})^{\mathrm{b}}\end{array}$ \\
\hline C. iberica & 10.06 & $55.82 \pm 0.61$ & $50.13 \pm 0.88$ & $190 \pm 0.49$ & $182.46 \pm 1.19$ & $79.08 \pm 5.11$ \\
\hline $\begin{array}{l}\text { C. urvillei ssp. } \\
\text { hayekiana }\end{array}$ & 12.41 & $17.18 \pm 0.86^{c}$ & $98.43 \pm 1.34$ & $1230 \pm 0.26$ & $402.08 \pm 5.74$ & $\begin{array}{c}186.08 \pm \\
2.05\end{array}$ \\
\hline $\begin{array}{l}\text { C. urvillei ssp. } \\
\text { nimrodis }\end{array}$ & 16.18 & $36.71 \pm 1.02$ & $75.04 \pm 1.07$ & $310 \pm 0.05$ & $243.91 \pm 3.72$ & $84.07 \pm 1.46$ \\
\hline Ascorbic acid & - & $4.23 \pm 0.32$ & - & - & - & - \\
\hline a-tocopherol & - & - & $123.65 \pm 0.6$ & - & - & - \\
\hline Trolox & - & - & - & $2520 \pm 0.92$ & - & - \\
\hline
\end{tabular}

Oleic acid (C 18:1 $\omega 9)$ and linoleic acid (C 18:2 $\omega 6)$ were determined to be major fatty acids in the oil of our samples. Oleic acid is the monounsaturated fatty acid which is important in human nutrition. Monounsaturated fat intake leads to a decrease in low-density lipoprotein (LDL) cholesterol and increased high-density lipoprotein (HDL) cholesterol. It is important to have a sufficient amount of linoleic acid in our diets because of its necessity. Lack of essential fatty acids such as linoleic acid in the body, mostly causes cardiovascular (and many other) diseases and its progression [27].

According to previous studies, the antioxidant capacity of extracts and their flavonoid content are related $[28,29]$. The TPC of the extracts of $C$. iberica, C. urvillei ssp. hayekiana, and C. urvillei ssp. nimrodis were determined as 182.46, 402.08, and 243.91 gallic acid equivalents $(\mathrm{mg} / \mathrm{g})$ dry matter. TFC of C. iberica, C. urvillei ssp. hayekiana, and C. urvillei ssp. nimrodis extracts $79.08 \%, 186.08 \%$, and $84.07 \%$, respectively. Similarly results in antioxidant capacity values, TPC and TFC concentrations Centaurea species were reported in previous studies [19,21,22]. Epidemiologic studies have shown an inverse relationship between foods with high antioxidant content and the rate of death from degenerative diseases such as cancer and heart disease [28]. Therefore the high antioxidant capacity of C. urvillei ssp. hayekiana is a very important result. Our results suggested that Centaurea oil and polyphenolics can be used as a potential source of natural antioxidants and for nutritional and pharmacological applications.

The present study was a preliminary attempt to characterize the nutritional value of C. iberica, C. urvillei ssp. hayekiana, and C. urvillei ssp. nimrodis as a potential natural source of antioxidants, proteins and oils. C. urvillei ssp. hayekiana showed relatively high unsaturated fatty acid content. Indeed, C. urvillei ssp. hayekiana methanol extract in particular exhibited significant total phenolic, flavonoid and high antioxidant potency.

Genetic and environmental factors regulate the phytochemical response of wild plants. Further studies that take into account environmental factors and genetic diversity are definitely needed. , C. urvillei ssp. hayekiana should attract attention as a natural source of protein, unsaturated fatty acids and natural antioxidants that can be used for nutritional, industrial and pharmaceutical purposes.

\section{MATERIALS AND METHODS}

\subsection{Plant materials}

The aerial parts of $C$. urvillei ssp. hayekiana, C. iberica, and C. urvillei ssp. nimrodis were collected during flowering period from rocky areas of Buzluk Cave, Harput, Elazıg, Turkey in June 2018. The plants were identified by Ugur Cakilcioglu from Tunceli University. Voucher specimens (no. 1460, 1461, and, 1459, 
respectively) were deposited in the Herbarium of Faculty of Pharmacy, Department of Pharmacognosy, Ege University, Izmir, Turkey.

\subsection{Chemicals}

All standarts and chemical compounds were purchased from Sigma Chemical Co. (Sigma-Aldrich Gmbh, Germany).

\subsection{Fatty acid analysis}

40 grams of ground sample were extracted for oil, using petroleum ether at $60^{\circ} \mathrm{C}$ for $6 \mathrm{~h}$ in a Soxhlet system. The solvent was evaporated by rotary evaporator. The obtained oil was esterified to determine fatty acid composition [27].

The method described by Ichihara et al. was followed to prepare fatty acid methyl esters (FAME) using transmethylation [28]. FAMEs were analyzed on a HP (Hewlett Packard) Agilent 6890N model gas chromatograph (GC), Agilent 5975C mass selective detector (MSD) and fitted to a HP-88 capillary column (100 $\mathrm{m}$ length, $0.25 \mathrm{~mm}$ i.d. and $0.2 \mu \mathrm{m}$ thickness). Injector and detector temperatures were set at 240 and $250{ }^{\circ} \mathrm{C}$, respectively. The oven was set at $160^{\circ} \mathrm{C}$ for $2 \mathrm{~min}$. The temperature was increased up to $140{ }^{\circ} \mathrm{C}$ at rate of 4 ${ }^{\circ} \mathrm{C} / \mathrm{min}$ then increased at up to $200^{\circ} \mathrm{C}$ at rate of $2{ }^{\circ} \mathrm{C} / \mathrm{min}$ and held at $200{ }^{\circ} \mathrm{C}$ for $46.75 \mathrm{~min}$. Total run time was arrenged as $70 \mathrm{~min}$ and as carrier gas helium was used $(1 \mathrm{~mL} / \mathrm{min})$. Identification of fatty acids was done by comparision of mass spectra and retention times with standarts (Supelco 37 Component FAME Mix and with the NIST 11 and Wiley 7 commercial mass spectral libraries). Quantification methyl esters of fatty acids was done using the internal standard mass and relative percentage of GC in relation to each component. Each reported result is given in the average value of three GC analyses. The results were determined as means \pm S.D.

\subsection{Extraction}

The aerial plant materials were dried at optimum conditions in the room temperature. Methanol extracts were prepared from $40 \mathrm{~g}$ batches of the air-dried and powdered plant materials by extracting with $400 \mathrm{~mL}$ methanol in a Soxhlet apparatus for $6-8 \mathrm{~h}$. The solvents were evaporated to dryness in vacuo $\left(40^{\circ} \mathrm{C}\right)$. Extracts were stored at $+4{ }^{\circ} \mathrm{C}$ in dark until use.

\subsection{Antioxidant activity assays}

\subsection{1. $\mathrm{DPPH}$}

DPPH free radical scavenging activity measurement was performed with some modifications on the Fukumoto method [29]. The measurement was made with a 96-well microplate. Microdilution sample batches $(1 \mathrm{mg} / \mathrm{mL}$, dissolved in HPLC grade $\mathrm{MeOH})$ were prepared starting with $150 \mu \mathrm{L} .50 \mu \mathrm{L}$ of DPPH reagent (100 $\mu \mathrm{M}$, prepared with HPLC grade $\mathrm{MeOH})$ was added to each well to give a total volume of $200 \mu \mathrm{L}$. The microplate was stored at room temperature in dark conditions and then absorbance was measured at $550 \mathrm{~nm}$ after 30 minutes with the aid of a BMG Labtech FluoStar Optima plate reader. For the blank control, HPLC grade $\mathrm{MeOH}$ was used instead of the sample. Ascorbic acid $(0.01 \mathrm{mg} / \mathrm{mL}$ in HPLC grade $\mathrm{MeOH})$ was used as standard. Evaluation of $\mathrm{IC}_{50}$ values was also done using the GraphPad Prism 6.05 program.

\subsubsection{ABTS}

ABTS [2,2'-azinobis (3-ethylbenzotiazolyn-6-sulfonic acid) diamonium salt] solution was prepared and diluted with ethanol until giving 0.750 absorbance in $734 \mathrm{~nm}$ by ABTS assay [30]. $0.1 \mathrm{ml}$ of extracts and $10 \mu 1$ a-tocopherol were added to $1 \mathrm{ml} \mathrm{ABTS}^{+}$solution and absorbance changing was observed in $734 \mathrm{~nm}$ during 6 minutes. For standard solution, a-tocopherol was used. \% ABTS rate was calculated by this equation:

$$
\% \mathrm{ABTS} \text { rate }=\left[\mathrm{Abs}_{1}-\mathrm{Abs}_{2}\right] / \mathrm{Abs}_{1} \times 100 .[\text { Eq. 1] }
$$

Abs: First measurement

$\mathrm{Abs}_{2}$ : Second measurement after 6 minutes

\subsubsection{CUPRAC}


In accordance with some modifications of the Apak method, the reducing power of $\mathrm{Cu}(\mathrm{II})$ was analyzed [31]. After the mixture of Neocouprin and $\mathrm{Cu}$ (II) solutions $(\mathrm{pH} 7$ ) was prepared, sample solut ons at various concentrations were added and after waiting for 30 minutes at room temperature, measurements were made at $450 \mathrm{~nm}$ absorbance. Trolox solution prepared at different concentrations was used for the standard.

\subsubsection{Determination of total phenolic and flavonoid contents}

Total phenolic content (TPC) was quantified using the Folin-Ciocalteu phenol reagent, while total flavonoid content (TFC) was measured using aluminium nitrate nonahydrate according to a slightly modified experimental procedure. The results were expressed as $\mathrm{mg} \mathrm{GAE} / \mathrm{g}$ and $\mathrm{mg} \mathrm{QE} / \mathrm{g}$ of dry extract, respectively by using Equation 2 and 3 [32-34].

\subsubsection{Statistical analysis}

All analysis of each sample were carried out three times and obtained results were showed as means \pm SD. One-way-analysis of variance (ANOVA) $(\mathrm{p}<0.05)$ was applied and Person's correlation was used to determine the correlation coefficient of total phenolic content and antioxidant activity (Microsoft excel 2013).

Acknowledgements: The authors would like to thank to Assoc. Prof. Ugur Cakilcioglu for collection of plants materials.

Author contributions: Concept - P.T., B.T.; B.K.; T.F.; Design - P.T., B.T.; B.K.; T.F.; Supervision - T.F.; B.K.; Resources - P.T., Materials - P.T.; B.T.; Data Collection and/or Processing - P.T., B.T.; B.K.; T.F.; Analysis and/or Interpretation P.T., B.T.; B.K.; T.F.; Literature Search - P.T., B.K.; Writing - P.T., B.T.; B.K.; T.F.; Critical Reviews - P.T., B.T.; B.K.; T.F.

Conflict of interest statement: The authors declared no conflict of interest.

\section{REFERENCES}

[1] Davis PH, Mill RR, Tan K. Flora of Turkey and the East Aegean Islands, University Press, Edinburgh, Vol.10 (Davis P.H. ed.), 1998, 489.

[2] Guner A, Ozhatay N, Ekim T, Baser KHC. Flora of Turkey and the East Aegean Islands, University Press, Edinburgh, Vol.11, 2000, 163.

[3] Wagenitz G, Flora of Turkey and the East Aegean Islands, University Press, Edinburgh, Vol.5 (Davis P.H. ed.) 1975, 536.

[4] Baytop T. Türkiye' de Bitkilerle Tedavi (Geçmişte ve Bugün), Nobel Tıp Kitabevleri, Istanbul, $1999,316$.

[5] Yesilada E, Sezik E, Honda G, Takaishi Y, Takeda Y, Tanaka T. Traditional medicine in Turkey IX. Folk medicine in northwest Anatolia. J Ethnopharmacol. 1999; 64: 195-210. [CrossRef]

[6] Sezik E, Yesilada E, Honda G, Takaishi Y, Takeda Y, Tanaka T. Traditional medicine in Turkey X: Folk medicine in central Anatolia. J Ethnopharmacol. 2001; 75: 95-115. [CrossRef]

[7] Arif R, Kupeli E, Ergun F. The biological activity of. Centaurea L. species (Review). Gazi Fac J Sci. 2004; 17: 149-164.

[8] Formisano C, Rigano D, Senatore F, Celik S, Bruno M, Rosselli S. Volatile constituents of aerial parts of three endemic Centaurea species from Turkey: Centaurea amanicola Hub.-Mor., Centaurea consanguinea DC. and Centaurea ptosimopappa Hayek and their antibacterial activities. Nat Prod Res. 2008; 22: 833-839. [CrossRef]

[9] Ugur A, Duru ME, Ceylan O, Sarac N, Varol O, Kivrak I. Chemical composition, antimicrobial and antioxidant activities of Centaurea ensiformis Hub.-Mor. (Asteraceae), a species endemic to Mugla (Turkey). Nat Prod Res. 2009; 23: 149-167. [CrossRef]

[10] Aktumsek A, Zengin G, Guler GO, Cakmak YS. Assessment of the antioxidant potential and fatty acid composition of four Centaurea L. taxa from Turkey. Food Chem. 2013; 141: 91-97. [CrossRef]

[11] Akkal S, Benayache F, Medjroubi K, Tillequin F, Seguin E. Flavonoids from Centaurea furfuracea (Asteraceae). Biochem Syst Ecol. 2003; 31: 641-643. [CrossRef]

[12] Tekeli Y, Sezgin M, Aktumsek A, Guler GO, Sanda MA. Fatty acid composition of six Centaurea species growing in Konya, Turkey. Nat Prod Res. 2010; 24: 1883-1889. [CrossRef]

[13] Senatore, F, Arnold NA, Bruno M. Volatile components of Centaurea eryngioides Lam. and Centaurea iberica Trev. var. hermonis Boiss.\&Lam., two Asteraceae growing wild in Lebanon. Nat Prod Res. 2005; 19: 749-754. [CrossRef] 
[14] Sham'yanov D, Akhmedov UA, Saidkhodzhaev AI. Sesquiterpene lactones and other components of Centaurea iberica. Chem Nat Compd. 1998; 34: 339-340.

[15] Dumlu MU, Gurkan EA. A new active compound from Centaurea species. Z Naturforsch C. 2006; 61: 44-46. [CrossRef]

[16] Bruno M, Maggio A, Rosselli S, Gedris TE, Herz W. Sesquiterpene lactones and other constituents of Centaurea paniculata ssp. castellana. Biochem Syst Ecol. 2002; 30: 379-381. [CrossRef]

[17] Zengin G, Cakmak VS, Guler GO, Aktumsek A. In vitro antioxidant capacities and fatty acid compositions of three Centaurea species collected from Central Anatolia region of Turkey. Food Chem Toxicol. 2010; 48: $2638-2641$. [CrossRef]

[18] Erdogan T, Gonenc T, Cakilcioglu U, Kivcak B. Fatty acid composition of the aerial parts of some Centaurea species in Elazig, Turkey. Trop J Pharm Res. 2014; 13: 613-616. [CrossRef]

[19] Janackovic P, Gavrilovic M, Vujisic L, Matevski V, Marin PD. Fatty acid composition of the cypselae of two endemic Centaurea species (Asteraceae). Bot Serb. 2017; 41: 3-9. [CrossRef]

[20] Ayaz FA, Ozcan M, Kurt A, Karayigit B, Ozogul Y, Glew R, Ozogul F. Fatty acid composition and antioxidant capacity of cypselas in Centaurea s.l. taxa (Asteraceae, Cardueae) from NE Anatolia. S Afr J Bot. 2017; 12: 474-482. [CrossRef]

[21] Zengin G, Gokalp OG, Cakmak YS, Aktumsek A. Antioxidant capacity and fatty acid profile of Centaurea kotschyi (Boiss. \& Heldr.) Hayek var. persica (Boiss.) Wagenitz from Turkey. Grasas Y Aceites. 2011; 62: 90-95. [CrossRef]

[22] Zengin G, Aktumsek A, Guler GO, Cakmak YS, Yildiztugay E. Assessment of the antioxidant potential and fatty acid composition of four Centaurea L. taxa from Turkey. Rec Nat Prod. 2011; 5: 123-132. [CrossRef]

[23] Dhouibi N, Manuguerra S, Arena R, Mahdhi A, Messina CM, Santulli A, Dhaouasi H. Screening of Antioxidant Potentials and Bioactive Properties of the Extracts Obtained from Two Centaurea L. Species (C. kroumirensis Coss. and C. sicula L. subsp sicula). App Sci. 2020; 10(7): 2267. [CrossRef]

[24] Polatoglu K, Sen A, Bulut G, Bitis L, Goren N. Essential oil composition of Centaurea stenolepis Kerner. from Turkey. J Ess Oil Bear Plants. 2015, 17(6): 1268-1278. [CrossRef]

[25] Karamenderes C, Konyalioglu S, Khan S, Khan IA. Total phenolic contents, free radical scavenging activities and inhibitory effects on the activation of NF-kappa B of eight Centaurea L. species. Phytother Res. 2007; 21: 488-491. [CrossRef]

[26] Shoeb M, MacManus SM, Jaspars M, Kong-Thoo-Lin P, Nahar L, Celik S, Sarker SD. Bioactivity of two Turkish endemic Centaurea species, and their major constituents. Rev Bras Pharmacog. 2007; 17(2): 155-159. [CrossRef]

[27] Parikh P, Mcdaniel MC, Ashen D, Millker JI, Sorrentino V, Chan V, Blumental RS. Diets and cardiovascular disease: an evidence-based assessment. J Am Coll Cardiolo. 2005; 45: 1379-1387. [CrossRef]

[28] Ichihara K, Shibahara A, Yamamoto K, Nakayama T. Preparation of fatty acid methyl esters by selective methanolysis of polar glycerolipids. Lipids. 1996; 31: 535-539. [CrossRef]

[29] Fukumoto LR, Mazza G. Assessing antioxidant and prooxidant activities of phenolic compounds. J Agric Food Chem. 2000; 48(8): 3597-3604. [CrossRef]

[30] Re R, Pellegrini N, Proteggente A, Pannala A, Yang M, Rice-Evans C. Antioxidant activity applying an improved ABTS radical cation decolorization assay. Free Radic Biol Med. 1999; 26(9-10): 1231-1237. [CrossRef]

[31] Apak R, Guclu K, Özyürek M, Karademir SE. Novel Total Antioxidant capacity index for dietary polyphenols and vitamins $\mathrm{C}$ and $\mathrm{E}$, using their cupric ion reducing capability in the presence of neocuproine: CUPRAC method. J Agric Food Chem. 2004; 52(26): 7970-7981. [CrossRef]

[32] Singleton VL, Rossi JA. Colorimetry of total phenolics with phosphomolybdic-phosphotungstic acid reagents. Am J Enol Viticult. 1965; 6: 144-158.

[33] Prior RL, Cao G. Antioxidant phytochemicals in fruits and vegetables: Diet and health implications. Horiculture Sci. 2000; 35: 588-592. [CrossRef]

[34] Sun, Y. Free radicals, antioxidant enzymes, and carsinogenesis. Free Rad Biol Med. 1990; 8: 583-599. [CrossRef] 